\title{
Hazard Analysis Critical Control Points (HACCP) Principle 7: Establish Record Keeping and Documentation Procedures ${ }^{1}$
}

Larry Eubanks, Chad Carr, and Ronald H. Schmidt ${ }^{2}$

The Hazard Analysis Critical Control Point (HACCP) is a system of preventative accountability for biological, physical, or chemical hazards which could be introduced or increased at a given point during the processing of a food product (NACMCF, 1998; Codex Alimentarius, 2003). Food processors can have a scientifically sound and validated HACCP plan, but poor record keeping can nullify all the effort to establish the system. Proper record keeping is an imperative part of the HACCP system for all food processors, regardless of whether the facility is federally regulated as with meat and poultry, fish, and juice, or whether the system is voluntary.

Both the United States Department of Agriculture's Food Safety Inspection Service (FSIS) and the Food and Drug Administration (FDA) regulations state that records must be developed and maintained for the monitoring of each critical control point. Depending on the regulatory agency, record keeping is either principle 6 or principle 7 of "the seven principles of HACCP." These regulations can be found in the Code of Federal Regulations for meat and poultry (CFR, 1996), for fish and fishery products (CFR 21-123, 1997), and for juice (CFR, 2001).

Complete and accurate HACCP records are beneficial to a processing plant operator because they:

1. Make it possible to trace ingredients, functions, or finished products should a problem occur along the process;

2. Help identify trends in the production system;

3. Serve as written documentation of your plant's compliance with the HACCP regulations; and

4. Protect both your customers and you.

There are two primary kinds of records processors should account for when establishing their record keeping procedures: overall program records and daily records (Scott and Stevenson, 2006). Overall program records would include all records which validate your HACCP plan, including records

1. This document is AN221, one of a series of the Animal Science Department, Florida Cooperative Extension Service, Institute of Food and Agricultural Sciences, University of Florida. Original publication date August 6, 2009. Visit the EDIS Web Site at http://edis.ifas.ufl.edu.

2. Larry Eubanks, coordinator of research programs, Department of Animal Science; Chad Carr, assistant professor, Department of Animal Science; and Ronald H. Schmidt, professor, Department of Food Science and Human Nutrition; Florida Cooperative Extension Service, Institute of Food and Agricultural Sciences, University of Florida, Gainesville, FL 32611.

The Institute of Food and Agricultural Sciences (IFAS) is an Equal Opportunity Institution authorized to provide research, educational information and other services only to individuals and institutions that function with non-discrimination with respect to race, creed, color, religion, age, disability, sex, sexual orientation, marital status, national origin, political opinions or affiliations. U.S. Department of Agriculture, Cooperative Extension Service, University of Florida, IFAS, Florida A. \& M. University Cooperative Extension Program, and Boards of County Commissioners Cooperating. Millie Ferrer-Chancy, Interim Dean 
that support the rationale used to establish: critical control points, critical limits, monitoring procedures and frequencies, and corrective action procedures. These overall program records should also include documentation of all verification procedures and frequencies. Daily records include all records that your facility uses on a day-to-day basis such as monitoring or corrective action logs.

Specifically the records which need to be developed and retained are:

1. Copies of training certificates for all members of the HACCP team documenting that each member has been trained in the seven principles of HACCP by a certified instructor;

2. An original, approved, signed \& dated HACCP plan for each product category a facility produces;

3. Descriptions and ingredient lists for all products which have active, approved HACCP plans;

4. A verified flow diagram;

5. All HACCP plan revisions, amendments, \& (re)validations;

6. Documentation of training for all HACCP monitors, verifiers, etc;

7. Monitoring records of critical control points for each HACCP plan within the facility;

8. Deviation summaries:

- What happened

- What product was involved (identity lot, line information, date, etc)

- When \& where did it happen

- Who recorded the deviation;

9. Corrective action summaries:

- What, when, where, who?

- Hold/trace records
- Disposition summaries

- Results of hazard evaluation (when needed);

10. Preventive actions developed \& implemented in response to deviations for each HACCP plan; and

11. Record review documents for FSIS pre-shipment review.

All HACCP records must contain the title and date of the record, product identification, the signature or initials of the employee making the entry, a place for the reviewer's signature, and an orderly manner for entering the required data. Records must be made at the time of the activity showing the date and time the record was made. Actual values for the monitoring activity must be legible. Some records can be initialed while others, such as a pre-shipment review, must be signed. In either case, the person who developed the record must be identified. There can be no scratch-outs, white-outs, arrows or ditto marks. If a mistake is made recording data, a single strike-out line should be made so the original entry is still legible and the correction must be initialed (Scott and Stevenson, 2006).

The record forms should be developed to protect the confidentiality of the company and the integrity of the record. Additionally, electronic records are acceptable as long as their integrity is assured; records should be "trustworthy, reliable and generally equivalent to paper records and handwritten signatures executed on paper" (CFR 21-11, 1997). Hardware, software and attendant documentation maintained electronically must be readily available for, and subject to, agency inspection.

HACCP Records for meat and poultry must be kept for at least 1 year for slaughter or refrigerated product and at least 2 years for frozen, preserved, or shelf-stable products (CFR, 1996). Juice is similar in that perishable or refrigerated juice records are to be kept for 1 year and records for frozen or shelf stable juice for two years (CFR, 2001; IDFA, 2006). In addition, the records must be kept on site for at least 6 months; after that, they may be kept off-site as long as they can be provided to an inspector within 24 
hours of an official request. Fish and fishery HACCP records may be transferred to some other reasonably accessible location at the end of the seasonal pack but shall be immediately returned for official review upon demand (CFR 21-123, 1997).

USDA requires a pre-shipment review of all documentation before products leave the production facility (CFR, 1996). The review ensures all critical limits were met, and that the proper corrective actions were taken if a deviation occurred. This review shall be conducted, dated, and signed by someone trained in HACCP principles and implementation who did not generate the initial records (Scott and Stevenson, 2006).

Regardless of agency, HACCP records must be accessible to regulatory personnel for review and, if needed, copying. It is strongly suggested that inspectors be required to sign out the records they request. HACCP plans and records are regarded as confidential documents and should not be distributed outside the company.

\section{Literature Cited}

Code of Federal Regulations. 1996. Title 9; part 417, Hazard analysis and critical control point (HACCP) systems; Final Rule. US Government Printing Office, Washington, DC.

Code of Federal Regulations. 1997. Title 21; part 123, Fish and fishery products HACCP regulation. US Government Printing Office, Washington, DC.

Code of Federal Regulations. 1997. Title 21; part 11, Electronic records and electronic signatures. US Government Printing Office, Washington, DC.

Code of Federal Regulations. 2001. Title 21; part 120, Juice HACCP regulation. US Government Printing Office, Washington, DC.

Codex Alimentarius. 2003. Hazard analysis and critical control point (HACCP) system and guidelines for its application. ANNEX to Recommended International Code of Practice/General Principles of Food Hygiene. CAC/RCP 1-1969, Rev 4. FAO/WHO Codex Alimentarius Commission.
International Dairy Foods Association (IDFA). 2006. Advanced HACCP Short Course for Dairy and Juice Products - Course Manual. IDFA, Washington, DC.

National Advisory Committee on Microbiological Criteria for Foods (NACMCF). 1998. Hazard analysis and critical control point principles and application guidelines. Journal of Food Protection, 61, 762.

Scott, V. N., and Stevenson, K. E. 2006. HACCP: A systematic approach to food safety. Washington, D.C. Food Products Association.

Schmidt, R. H., and Newslow, D. L. 2007. Hazard analysis critical control points (HACCP) Getting started, preliminary steps (FSHN0701). Gainesville: Department of Food Science and Human Nutrition, Florida Cooperative Extension Service, Institute of Food and Agricultural Sciences, University of Florida. Retrieved July 14, 2009, from http://edis.ifas.ufl.edu/FS137.

Schmidt, R. H., and Newslow, D. L. 2007. Hazard analysis critical control points (HACCP) Prerequisite programs (FSHN0702). Gainesville: Department of Food Science and Human Nutrition, Florida Cooperative Extension Service, Institute of Food and Agricultural Sciences, University of Florida. Retrieved July 14, 2009, from http://edis.ifas.ufl.edu/FS138.

Schmidt, R. H., and Newslow, D. L. 2007. Hazard analysis critical control points (HACCP) Principle 1: Conduct a Hazard Analysis (FSHN0703). Gainesville: Department of Food Science and Human Nutritions, Florida Cooperative Extension Service, Institute of Food and Agricultural Sciences, University of Florida. Retrieved July 23, 2009, from http://edis.ifas.ufl.edu/FS139.

Schmidt, R. H., and Newslow, D. L. 2007. Hazard analysis critical control points (HACCP) Principle 2: Determine Critical Control Points (CCPS) (FSHN0704). Gainesville: Department of Food Science and Human Nutrition, Florida Cooperative Extension Service, Institute of Food and Agricultural Sciences, University of Florida.

Retrieved July 23, 2009, from http://edis.ifas.ufl.edu/FS140. 
Schmidt, R. H., and Newslow, D. L. 2007.

Hazard analysis critical control points (HACCP) -

Principle 3: Establish Critical Limits and Principle 4:

Monitoring Critical Control Points (CCPs)

(FSHN0705). Gainesville: Department of Food

Science and Human Nutrition, Florida Cooperative

Extension Service, Institute of Food and Agricultural

Sciences, University of Florida. Retrieved July 23,

2009, from http://edis.ifas.ufl.edu/FS141.

Schmidt, R. H., and Newslow, D. L. 2007.

Hazard analysis critical control points (HACCP) -

Principle 5: Establish Corrective Actions

(FSHN0706). Gainesville: Department of Food

Science and Human Nutrition, Florida Cooperative

Extension Service, Institute of Food and Agricultural

Sciences, University of Florida. Retrieved July 23,

2009, from http://edis.ifas.ufl.edu/FS142.

Schmidt, R. H., and Newslow, D. L. 2007.

Hazard analysis critical control points (HACCP) -

Principle 6: Establish Verification Procedures

(FSHN0707). Gainesville: Department of Food

Science and Human Nutrition, Florida Cooperative

Extension Service, Institute of Food and Agricultural

Sciences, University of Florida. Retrieved July 24,

2009 from http://edis.ifas.ufl.edu/FS143. 